DOI:10.30842/ielcp230690152346

Antonio Corso

(Kanellopoulos Foundation / Messenian Society, Athens, Greece)

\title{
THE MASTERS \\ OF THE MAUSOLEUM OF HALICARNASSUS
}

The aim of this article is to try to identify the sculptors mentioned by ancient writers in the surviving sculptural evidence of the Mausoleum of Halicarnassus. The free-standing sculptures will be the main focus of this study because in antiquity free-standing sculpture enjoyed a higher status than reliefs. My research is based on stylistic comparison of these sculptures with other known works attributed to the respective sculptors. The outcome is a series of attributions of the most noteworthy sculptures from the Mausoleum to the masters who are known to have worked on this enterprise.

Keywords: Ancient Greek sculptures, Mausoleum of Halicarnassus, attribution of sculptures.

A. Kopco

(Kanellopoulos Foundation / Messenian Society, Афины, Греция)

\section{Мастера Галикарнасского мавзолея}

Цель статьи - попытаться идентифицировать скульпторов, упоминаемых античными авторами, по сохранившимся скульптурам из Галикарнасского мавзолея. В центре внимания находятся отдельно стоящие скульптуры, поскольку в то время они обладали более высоким статусом, чем рельефы. Исследование основывается на стилистическом сравнении этих скульптур с другими работами, приписываемыми тем или иным мастерам. В результате для целой серии наиболее значительных скульптур из Галикарнасского мавзолея определяется принадлежность скульпторам, которые, как известно, работали там.

Ключевые слова: древнегреческая скульптура, Галикарнасский мавзолей, атрибуция скульптур.

\section{Introductory remarks.}

The aim of this study is to try to recognize the styles of the masters known from the ancient tradition to have worked on the Mausoleum of Halicarnassus in the extant evidence of sculptures coming from this monument.

This attempt will be conducted through comparison between Mausoleum sculptures and other works attributed to these sculptors.

First of all, it is necessary to give few details about the Mausoleum. 


\section{The monument.}

The Mausoleum of Halicarnassus is one of the most renowned monuments of the ancient world ${ }^{1}$.

Mausolus must have decided to set up his monumental tomb in the centre of his newly built capital toward the end of his life: he died in $353 \mathrm{BC}^{2}$.

After his death, some writers who were renowned in the oratory - Theopompus, Theodectes, Naucrates and less certainly Isocrates went to the Hecatomnid court at Halicarnassus and took part in the competition held in the capital of Caria in order to deliver the most convincing oration on the death of Mausolus. The agon was won by Theopompus (Hornblower 1982: 334). Poets had also been invited on the same occasion (Hornblower 1982: 334-337). After the death of this satrap, the Mausoleum was continued by his wife and successor Artemisia (353-351 BC) and finished after her death (Pliny 36. 30-31), thus during the rule of Ada and Idrieus (351-344 $\mathrm{BC})$.

The shape of the building is known only generically thanks to the detailed description of the monument given by Pliny 36. 30-31 as well as to surviving elements of the tomb.

The Mausoleum was composed of a rectangular podium containing the tomb of the satrap, above which there was a templelike structure endowed with a peristasis, which was topped by a pyramidal roof, made of steps and supporting a marble quadriga.

The architects who had been responsible of the Mausoleum were Satyrus and Pytheus, who also wrote a treatise 'About the Mausoleum' (Vitruvius 7, praef. 12 and Laterculi Alexandrini 7. 15-17).

Satyrus was a Parian and is known also thanks to his signature on the base of bronze statues of Ada and Idrieus offered by the Milesians to Apollo Pythios at Delphi ${ }^{3}$. Thus he was both architect and bronze sculptor, closely linked to the Hekatomnid court and he worked for Ionian patrons.

Pytheus was an Ionian architect who after the Mausoleum became responsible of the temple of Athena at Priene: he wrote a

\footnotetext{
${ }^{1}$ About the Mausoleum, see especially Waywell 1978; Jeppesen 19812002; Hoepfner 2002: 417-423; Cook 2005 and Jenkins 2010: 121-135.

${ }^{2}$ About Mausolus, see especially Hornblower 1982; Ruzicka 1992 and Carstens 2009: 37-74.

${ }^{3}$ Waywell 2004: 366-367 and Hallof and Kansteiner 2014: 471-473.
} 
treatise also about this temple (Vitruvius 7. Praef. 12) ${ }^{4}$. Moreover probably he was the sculptor of the quadriga on top of the Mausoleum (Pliny 36. 31 reports the name of the author as Pythis: probably an adaptation of Pytheus to Latin).

The general concept of the architecture was rooted in the building tradition of Asia Minor: the emphasis given to the tomb of the dynast and its conception as a vertical succession, from bottom to top, of podium with the real tomb and temple-like structure with a peristasis was also not unknown to the early $4^{\text {th }} \mathrm{c}$. architecture, especially of Lycia.

However the novelty of this monument consisted in its unusually great dimensions, probably in the rational, homogeneous and modular design of the architectural complex, which transformed it into a typically Ionian creation, as well as in its extremely lavish sculptural decoration.

\section{The sculptural display on the monument.}

In fact, both Vitruvius (2. 8. 11 and 7. Praef. 12-13) and Pliny (36. 30-31) insist that the high quality of the sculptures was the most salient feature of the building.

There were both free-standing statues ${ }^{5}$ and reliefs ${ }^{6}$.

The sets of free-standing statues consisted of:

A. The chariot group on top of the building;

B. The lions, probably set up on the steps of the pyramidal roof;

C. Colossal standing figures. These statues are divided among: 1. Dynastic portraits; 2. A sacrificial group; and 3. A hunting group.

D. Heroic standing figures: probably both gods and human draped figures.

E. Life-size statues, probably fighting groups ${ }^{7}$.

The placement of these series in the building is a vexata quaestio.

Certainly colossal figures - probably dynastic portraits - stood in the intercolumns of the peristasis, in continuity with the previous adoption of the same display in the Nereids' monument of Xanthus in Lycia around 375 BC. (Hoepfner 2004: 334-338).

\footnotetext{
${ }^{4}$ Hoepfner 2004: 334-338 and Kansteiner and Seidensticker 2014: 506509.

${ }^{5}$ The standard catalogue of the free-standing sculpture of the Mausoleum is that of Waywell 1978.

${ }^{6}$ The most complete catalogue of the reliefs of the Mausoleum is that of Cook 2005.

${ }^{7}$ Waywell 1978; Carstens 2007: 37-74.
} 
The relief sculptures consisted of:

A. a frieze with an Amazzonomachy;

B. a frieze with a Centauromachy;

C. carved coffers;

D. a chariot frieze (Cook 2005).

Vitruvius and Pliny provide lists of sculptors who were responsible for the sculptures of the Mausoleum.

Vitruvius 7. Praef. 12-13 gives the following account:

"Satyrus and Pytheus published a book on the Mausoleum. And on these last, good fortune conferred the greatest and highest boon, for their works are adjudged to have a merit which is famous throughout the ages and of unfolding freshness and they employed distinguished artists on their undertakings. For on the single sides, different rival artists took their share in decorations wherein they competed: Leochares, Bryaxis, Scopas, Praxiteles, and some add Timotheus. The outstanding excellence of their work caused the fame of the Mausoleum to be included in the seven wonders of the world." (transl. Granger)

The Roman writer on architecture specifies that he depends on the treatise written by Satyrus and Pytheus on the Mausoleum. Treatises of architects of archaic and classical periods about buildings designed by them probably provided an analytic description of the main features of these monuments, technical details, a justification of the budget used on purpose and names of craftsmen and artists employed: these treatises may have been addressed first of all to the patrons or authorities who hired them. However, since they survived until the age of Vitruvius and came to be known by him, probably these books targeted also a broader public and copies of them were kept in the time of Vitruvius in libraries ${ }^{8}$.

Thus Vitruvius' information taken from this treatise is reliable because it is hardly believable that Satyrus and Pytheus could convey inaccurate data to their patrons (Mausolus, Artemisia, Ada and Idrieus) and to their public.

The writer informs that each side was given out - probably on contract - to a renowned artist. The works of these artists aimed at two goals:

A. Ad ornandum: probably this expression refers to the beautifying activity undertaken by each artist on his own side ${ }^{9}$;

\footnotetext{
${ }^{8}$ About these treatises, see Svenson-Evers 1996: 7-49; 67-99; 116-150; 157-211 and 320-329. Vitruvius may have seen the Mausoleum of Halicarnassus: see Jeppesen 1981-1983: 85-98.

${ }^{9}$ About this meaning of the word, see Gros 2006: 389-398.
} 
B. Ad probandum: this specification may refer to the circumstance that their works won the general approval for the monument ${ }^{10}$.

Thus Vitruvius mentions the artists who worked for the single sides. These artists are four, thus corresponding to the four sides of the monument. They are Leochares, Bryaxis, Scopas and Praxiteles. A fifth artist is mentioned: Timotheus.

Since all of these five artists were sculptors, thus their activity on the sides of the monument must have consisted of making sculptures to be set up on the building.

Leochares was an Athenian master beloved by Plato (this deduction is argued by the Platonic Epistula 13. 361 a) ${ }^{11}$. Mausolus was subjected to the influence of the philosopher Eudoxus of Cnidus, a former pupil of Plato (Corso 2007a: 26-36). Thus it is hardly surprising that a sculptor who was close to the Platonic environment was hired for the Mausoleum. The same sculptor was also regarded the sculptor of a colossal acrolithic statue of Ares for the sanctuary of this god at Halicarnassus (Vitruvius 2. 8.11) ${ }^{12}$. Of course this detail suggests that he worked for the Hecatomnids.

Bryaxis was also a sculptor: his name has been thought to reveal that he was of Carian descent, although he was an Athenian ${ }^{13}$ : he carved a marble Dionysus set up on Cnidus (Pliny 36. 22) - a city which was under Hecatomnid rule - and moreover he made statues of gods for Rhodes (Pliny 36. 42), which also became a Hecatomnid possession ${ }^{14}$, and of Zeus and Apollo for the Lycian city of Patara (Clement, Protrepticus 4. 47). Thus his activity for Halicarnassus fits his strong links with patrons of south-western Asia Minor quite well.

Scopas was Parian as Satyrus, thus it is not impossible that it was Satyrus who invited his fellow countryman to join this enterprise. Moreover around 355 he probably was already rather

\footnotetext{
${ }^{10}$ About the possible meaning of probatio, see Geraci 2004: 155-181.

${ }^{11}$ This is not the place to discuss the controversial problem of the attribution of the Platonic letters to the philosopher, which is guaranteed by the manuscript tradition. I believe the $13^{\text {th }}$ letter had been written by him.

${ }^{12}$ About Leochares, see Schultz 2007: 205-233 and Hallof, Kansteiner and Lehmann 2014 a: 210-229. About acrolithic statues, see Despinis 2004: 243-301.

${ }^{13}$ About Bryaxis, see Vollkommer 2001: 122-125 and Hallof, Kansteiner and Lehmann 2014 b: 478-506.

${ }^{14}$ See bibliography cited in note 2 .
} 
well established because very likely he had already carved his Hestia for the pritaneum of Paros ${ }^{15}$.

Finally Scopas also worked for Cnidus, where his statues of Athena and Dionysus had been set up (Pliny 36. 22) as well as for other important monuments of Asia Minor (Apollo Smintheus at Krise, his group of Poseidon, Achilles, Thetis with a sea thiasos probably from Bithynia as well as his works for the new Artemision of Ephesus $)^{16}$. His link with the Hecatomnid dynasty is argued also by the facts that Scopas, after the completion of the Mausoleum at around $345 \mathrm{BC}$, designed the temple of Athena Alea at Tegea (Oestby 2014: 2. 317-351) and that a relief representing the Carian rulers Ada and Idrieus has been found at Tegea (Loehr 2000: 110111), perhaps dedicated by Carian craftsmen who moved from Halicarnassus to Tegea in order to build the new temple: thus it is possible that the Skopas' temple was achieved with the support of the satrap of Caria Idrieus (Tandy 2013: 65-75).

Finally the collaboration of Praxiteles to the enterprise of the Mausoleum does not need a justification: toward $350 \mathrm{BC}$ he was famous and the setting of the Cnidian Aphrodite at Cnidus must have established his positive fame in Caria in the fields of marble sculpture and of young female statues ${ }^{17}$.

The first four masters mentioned by Vitruvius must be related to the most important sculptures which adorned the monumental tomb, $i$. e. to the free-standing sculptures.

The name of Timotheus is added to the series of the four masters related to the four sides of the building: toward the middle of the $4^{\text {th }}$ c. he must have been in the late phase of his activity ${ }^{18}$. The presence of his works at Halicarnassus is confirmed by the information, handed down by Vitruvius 2. 8. 11, that he may have worked on the colossal acrolithic statue of Ares set up in the sanctuary of this god at Halicarnassus.

Since his fame was mainly due to his acroteria and typoi carved around 375 for the temple of Asclepius near Epidaurus (Yalouris

\footnotetext{
${ }^{15}$ About Scopas, see Calcani 2009: 51-55 and 122; Katsonopoloulou and Stewart 2013 and Vorster, Lehmann and Zerhoch 2014: 417-470. About his Hestia, see Gruben 1999: 296-317.

${ }^{16}$ Calcani 2009: 131-135.

${ }^{17}$ Corso 2007b: 173-197. About Praxiteles, see Corso 2004-2014 and Soeldner, Hallof, Krumeich and Seidensticker 2014: 49-209.

${ }_{18}$ About Timotheus, see Stewart 2004: 475-479 and Kansteiner, Lehmann and Prignitz 2014: 277-285.
} 
1999, particularly 67-83), it is likely that he was hired because of his specialization in the specific field of architectural sculpture.

Pliny 36. 30-31 is more detailed about the carving of Mausoleum' sculptures by famous masters:

"The contemporaries and rivals of Scopas were Bryaxis, Timotheus and Leochares, whom we must discuss along with him because together with him they worked on the carvings (caelavere) of the Mausoleum. This is the tomb that was built by Artemisia for her husband Mausolus, the viceroy of Caria, who died in the second year of the $107^{\text {th }}$ Olympiad. These artists were chiefly responsible for making the structure of one of the seven wonders of the world. On the north and south sides it extends for 63 feet, but the length of the facades is less, the total length of the facades and sides being 440 feet. The building rises to a height of 25 cubits and is enclosed by 36 columns. The Greek word for the surrounding colonnade is 'pteron', 'a wing'. The east side was carved (caelavit) by Scopas, the north by Bryaxis, the south by Timotheus and the west by Leochares; and before they completed their task, the queen died. However, they refused to abandon the work without finishing it, since they were already of the opinion that it would be a memorial of their own glory and that of their profession; and even today they are considered to rival each other in skill. With them was associated a fifth artist. For above the colonnade there is a pyramid as high as the lower structure and tapering in 24 stages to the top of its peak. At the summit there is a 4-horse chariot of marble, and this is made by Pythis. The addition of this chariot rounds off the whole work and brings it to a height of 140 feet." (transl. Eichholz)

Pliny lends support to the fact that Scopas, Bryaxis, Timotheus and Leochares competed each other in order to carve the sculptures of the Mausoleum. From his exposition it appears clearly that Scopas was regarded the most important of the four masters. In fact he carved the eastern side, which of course was the privileged one the 'front' of the tomb, looking toward the palace of the satrap. The second most important side probably was the southern one, which could be admired from the sea: probably not by chance it was given to the second most important sculptor of the four mentioned by Pliny: Timotheus, who was already well established because of his activity at Epidaurus. The third side in order of importance probably was the western one, which could be seen from the boats entering the harbor: it was given to Leochares, probably already appreciated by Plato. The less important side was the northern one, looking toward the upper part of the city, and was assigned to Bryaxis: perhaps this sculptor was not yet well established.

Pliny determined the activity of these sculptors with the verb caelo used twice. This verb is more appropriate to the reliefs of the 
building than to free-standing sculptures (TIL, s. v. Caelo). The context in which this verb is used also lends support to this interpretation: in fact Pliny 36. 30 specified that the four sculptors 'carved' (caelavere) the Mausoleum - i. e. the building itself - not statues to be set up on the building. In 36.31 he details that the four sculptors 'carved' (caelavit) from east, north, south and west: of course the understood object of the verb is again the Mausoleum. This phrase conveys the image of the sculptor who carves the building directly from one side, not of the sculptor who carves statues which will be erected on the building. The conclusion of this reasoning is that Pliny with his report informs about the sculptors who made the reliefs of the Mausoleum.

At this point of our investigation, the problem arises about the writers who are the sources of this section of Pliny's encyclopedia. He does not use Satyrus' and Pytheus' treatise because he does not mention it in the bibliography used for the $36^{\text {th }}$ book, given in his $1^{\text {st }}$ book. Among the writers included in this bibliography, good candidates to have been used by Pliny for his information about the Mausoleum are Duris, Pasiteles, Varro and Mucian: it is difficult to choose among them.

There is another question which arises: why Pliny mentions the less important reliefs of the building and not the most praised freestanding statues? Were the latter damaged by the fire and sack of the city caused by Alexander the Great in 334 (Diodorus 17. 23. 4-27. 6 and Arrian 1. 20. 5-23. 6) or plundered by Verres in 80-79 BC (Cicero, In Verrem 2. 1. 49) or by the pirates in 62-58 BC (Cicero, Ad Quintum fratrem 1. 1. 25)? ${ }^{19}$ The circumstance that the excavations on the site led to the recovery of very few statues or fragments of them pertaining to the Mausoleum lends support to this hypothesis ${ }^{20}$.

In any case, the combination of the testimonia of Vitruvius and Pliny leads to the conclusion that Scopas, Leochares and Bryaxis made both statues and reliefs, Timotheus especially reliefs and perhaps also statues, Praxiteles only statues. It is likely that the specialization of Praxiteles' workshop in carving statues led to the request by Satyrus and Pytheus to this atelier only of free-standing sculptures.

${ }_{19}$ About these episodes, see Flensted-Jensen 2004: 1115-1116.

${ }^{20}$ About these issues, see also Lucchese 2009, particularly 39-55. 
Prior to examining the surviving sculptures of the Mausoleum in search for evidence of the styles of these masters mentioned by the two Latin writers, it is necessary to point out two observations:

A. During the late classical times, some of the best established workshops began producing works at an industrial pace: of course not any work made in these ateliers was by the hands of the main masters, but often assistants did much of these products while in other cases not all the parts were properly finished. For example Praxiteles in the late phase of his production used to leave unfinished parts of statues which were destined not to be visible (especially Choricius, Declamationes 8. 59 and Codex Vaticanus Graecus 989. 110). The Hermes of Olympia is an important example of this habit ${ }^{21}$. The quality of the baby Dionysus carried by the Hermes of Olympia is not outstanding and thus is hardly by the hand of such a renowned master as Praxiteles: probably it had been carved by assistants. Of course a lot of statues produced in these ateliers must have been made not by the main masters but by assistants.

Thus the fact that sculptures set up in the Mausoleum were delivered by the workshops of the above mentioned sculptors does not necessarily mean that they were all made by the hands of these famous masters: these sculptors may have sent their assistants to carve them.

B. Specifically concerning the reliefs of the Mausoleum, it is necessary to underline that during the classical period, the most important masters used not to carve architectural sculptures with their own hands but made small size models (proplasmata) which were transformed by assistants into real sculpture. For example, Schweitzer demonstrated that Phidias made the models of the Parthenon sculptures and that several sculptors used these models in order to carve metopes, frieze and pediments (Schweitzer 1967: 3254).

By analogy, we can suppose that Scopas, Timotheus, Bryaxis and Leochares carved the models of the friezes of the Mausoleum and that large workshops of Ionian craftsmen took inspiration from these models in order to carve the reliefs.

This suggestion would explain:

\footnotetext{
${ }^{21}$ Stampolidis 2007: 90-97, no. 14. The information about the 1500 works made by Lysippus (Pliny 34. 37) makes sense only if we accept that a lot was made by junior craftsmen. The pictura compendiaria adopted by the painters Nicomachus (Pliny 35. 145) and Philoxenus (Pliny 35. 110) also implies the need to make a lot of pictures in short time.
} 
A. the homogeneous style of the Mausoleum's reliefs, which implies their actual carving by workshops sharing style and rendering technique ${ }^{22}$; and

B. the circumstance that nevertheless stylistic patterns of the four masters can be detected on these slabs ${ }^{23}$.

Concerning the free-standing statues of the Mausoleum, the following materials may be attributed to the workshops of the masters mentioned by Vitruvius.

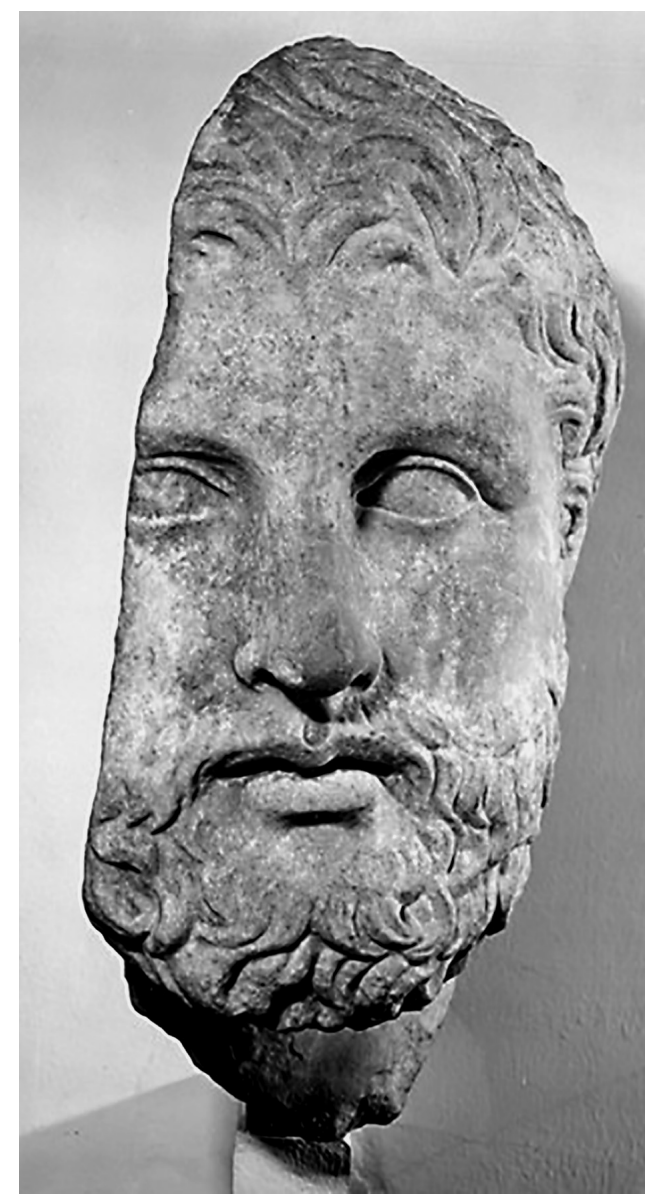

Fig. 1. Marble head, London, The British Museum, Greek and Roman Department, no. 1054 Roman no. 1054 Repartment, no.
(photo courtesy of late Prof. G. B. Waywell).

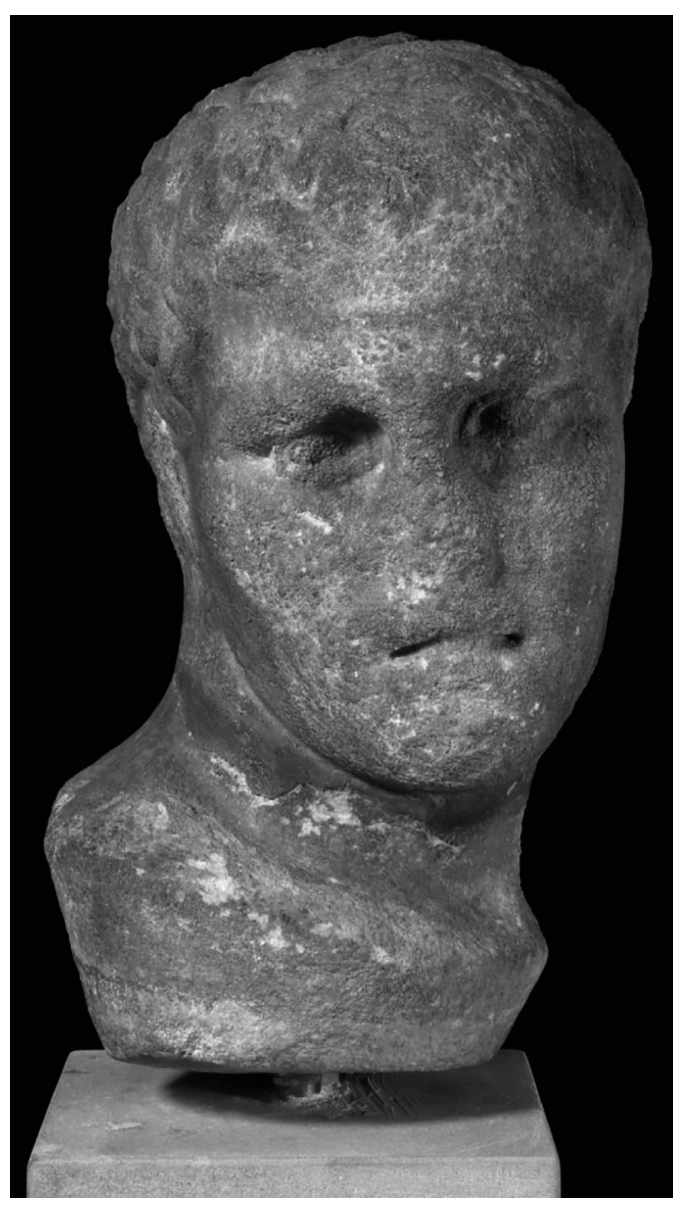

Fig. 2. Marble head, London, The British Museum, Greek and Roman Department, no. 1056

\section{Sculptures to be attributed to Scopas.}

The marble head at London, BM 1054 (Fig. 1) pertaining to the heroic statues ${ }^{24}$, reveals the seal of the workshop of Scopas in its rectangular concept, in its depiction of beard and hair with short

\footnotetext{
22 This opinion is that stressed by Cook 2005.

${ }^{23}$ This is the opinion asserted by Lucchese 2009 and Calcani 2009.

${ }^{24}$ Waywell 1978: pl. 20 and Lucchese 2009: pl. 2 b.
} 
curved locks which adhere rather closely to the skull, in its square forehead, in the deeply cut eye-sockets and in the concept of the mouth made by a long centrally curved upper lip and by a short outward lip.

Equally the young male head at London, BM 1056 (Fig. 2), pertaining to the life size statues (Waywell 1978: pl. 21), with an energetic pose, a pathetic expression and a Scopadic anatomic grammar, also may be attributed to the same atelier.

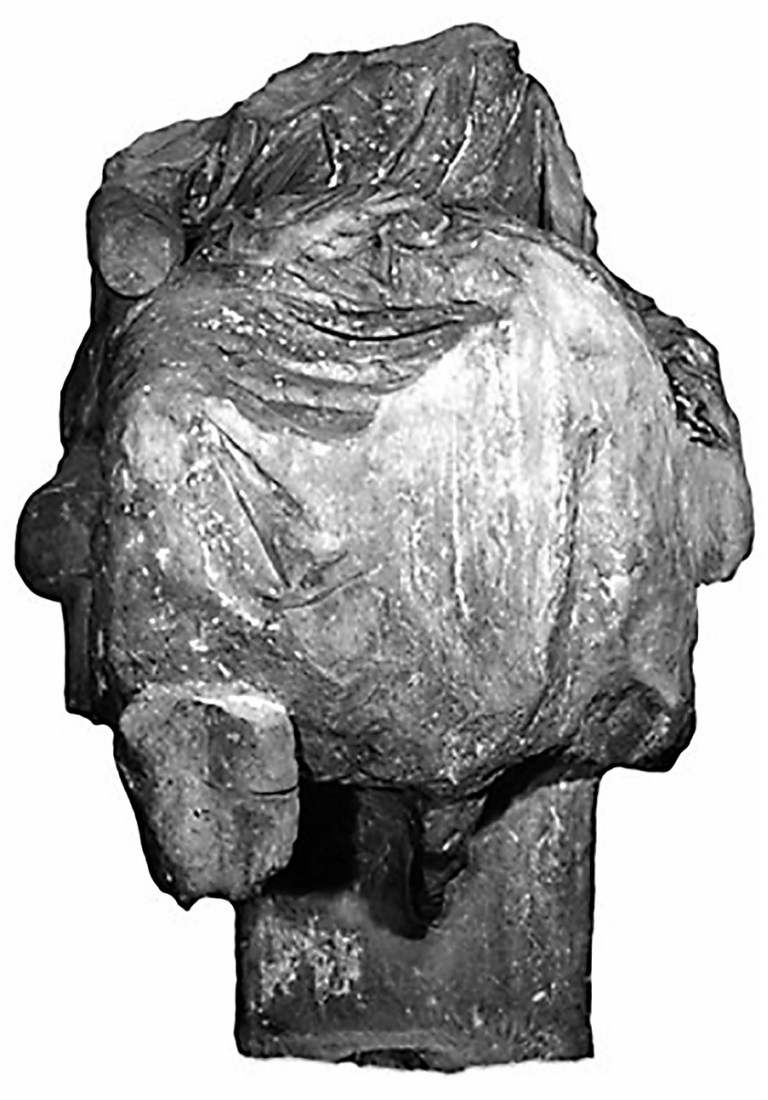

Fig. 3. Draped seated Man, marble, London, The British Museum, Greek and Roman Department, no. 1047 (photo courtesy of late Prof. G. B. Waywell).

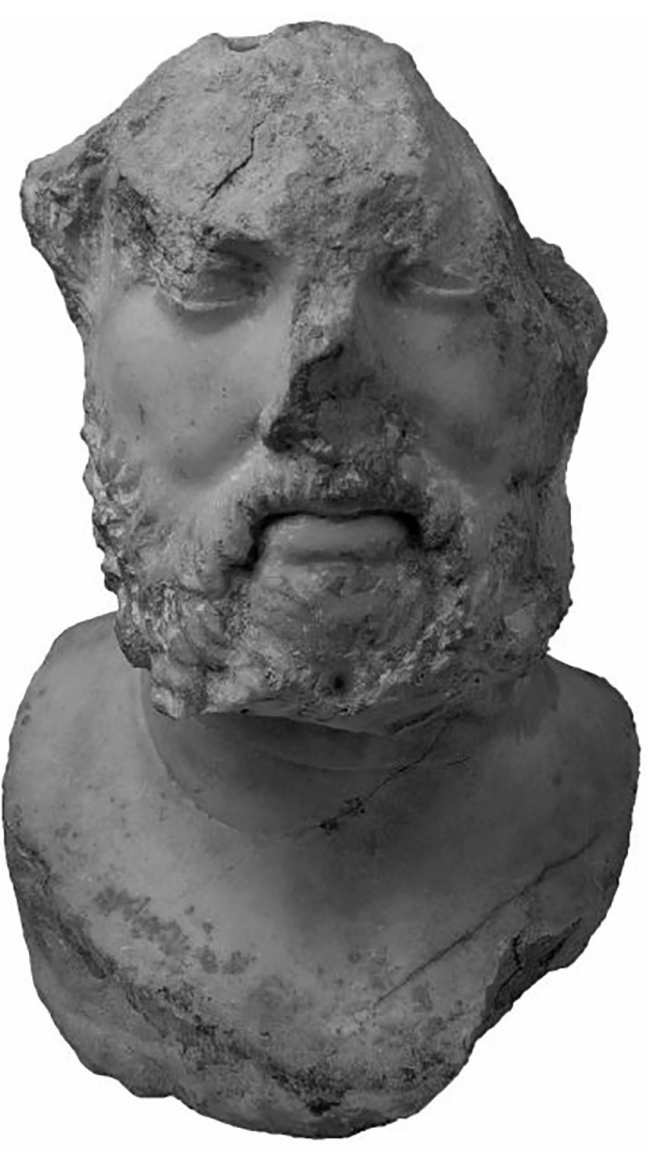

Fig. 4. Marble head, London,

The British Museum, Greek and Roman Department, no. 1055

\section{Sculptures to be attributed to Timotheus.}

Concerning the draped seated man, pertaining to the colossal figures, at London, BM 1047 (Fig. 3) ${ }^{25}$, the general concept of the

${ }^{25}$ Waywell 1978: pl. 17, no. 33 and Lucchese 2009: 131 and pl. 3, a. K. Jeppesen 2002: 5. 194-199 supposes that this enthroned figure had been accomodated in a recess in an imaginary doorway reserved within the masonry of the upper podium and placed in the middle of the east front. This hypothesis is not based on sound evidence. However the freshness of 
seating figure and of its drapery with its folds is so closely related to the corresponding features of sculptures from the temple of Asclepios at Epidauros, that it is tempting to attribute it to the workshop of Timotheos and to argue that, in keeping with the report of Vitruvius, he may have worked also for statues of the tomb.

The bearded male head, perhaps pertaining to the life size statues, at London, BM 1055 (Fig. 4) ${ }^{26}$, may be ascribed to the workshop of Timotheos, because of the preservation of a concept of head which is still typical of the post-Pheidian tradition and moreover because the anatomic grammar of the head finds comparison in heads from the Asclepieion of Epidaurus ${ }^{27}$.

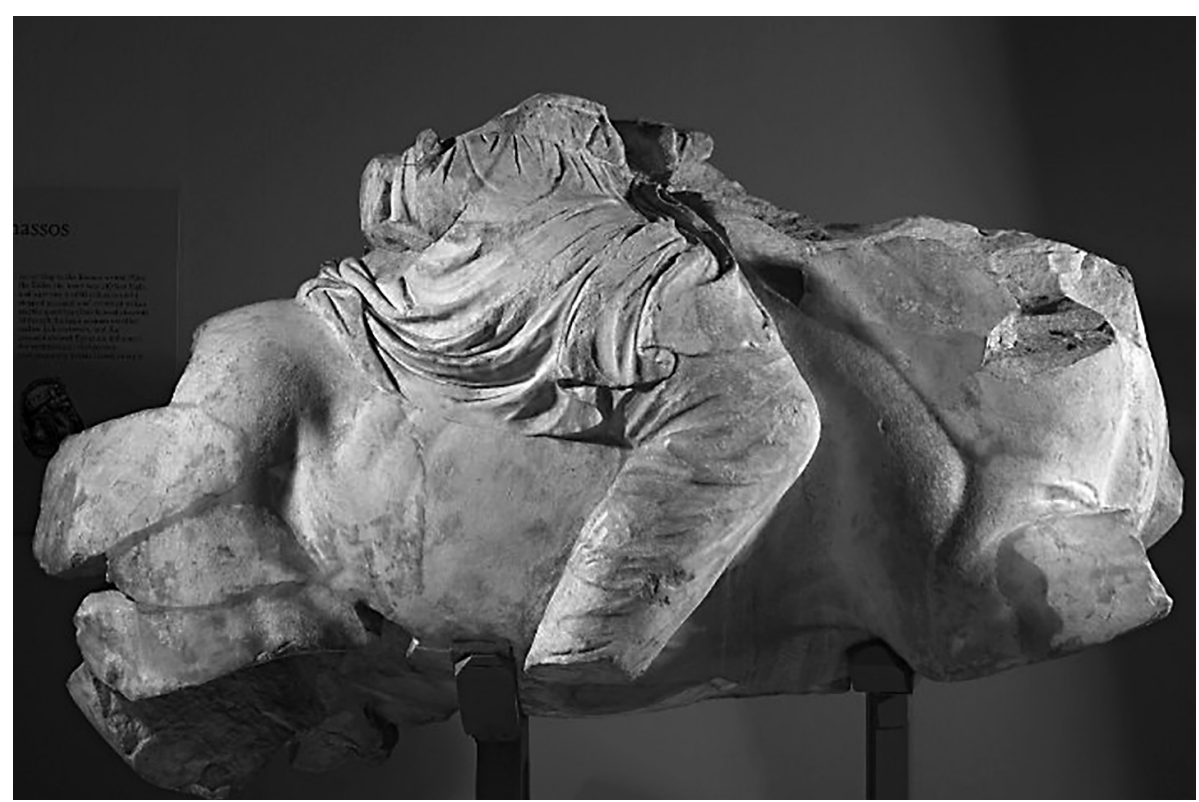

Fig. 5. Persian rider, marble, London, The British Museum, Greek and Roman Department, no. 1045 (photo courtesy of late Prof. G. B. Waywell).

\section{Sculptures to be attributed to Leochares.}

Leochares' art can be recognized in the colossal Persian rider at London, BM 1045 (Fig. 5) ${ }^{28}$, because of the wavy rendering of

the surface, when preserved, of this statue suggests that it was set up in a place which shielded it from weathering.

${ }^{26}$ Waywell 1978: pl. 22, no. 47.

27 Yalouris 1992: pls. 2 b; 9 b; 12 b; 19 a; 20 a; 30; 46 b; 47 c-d; 52 a and 53 a.

${ }^{28}$ Waywell 1978: pl. 18, no. 34 and Lucchese 2009: pl. 3 b. For the wavy rendering of drapery's folds in the oeuvre of Leochares, see Todisco 1993: fig. 219 (Vatican type of Ganymedes kidnapped by the eagle) and 226 (Belvedere type of Apollo). 
drapery's folds which is one of the most peculiar features of the art of this master.

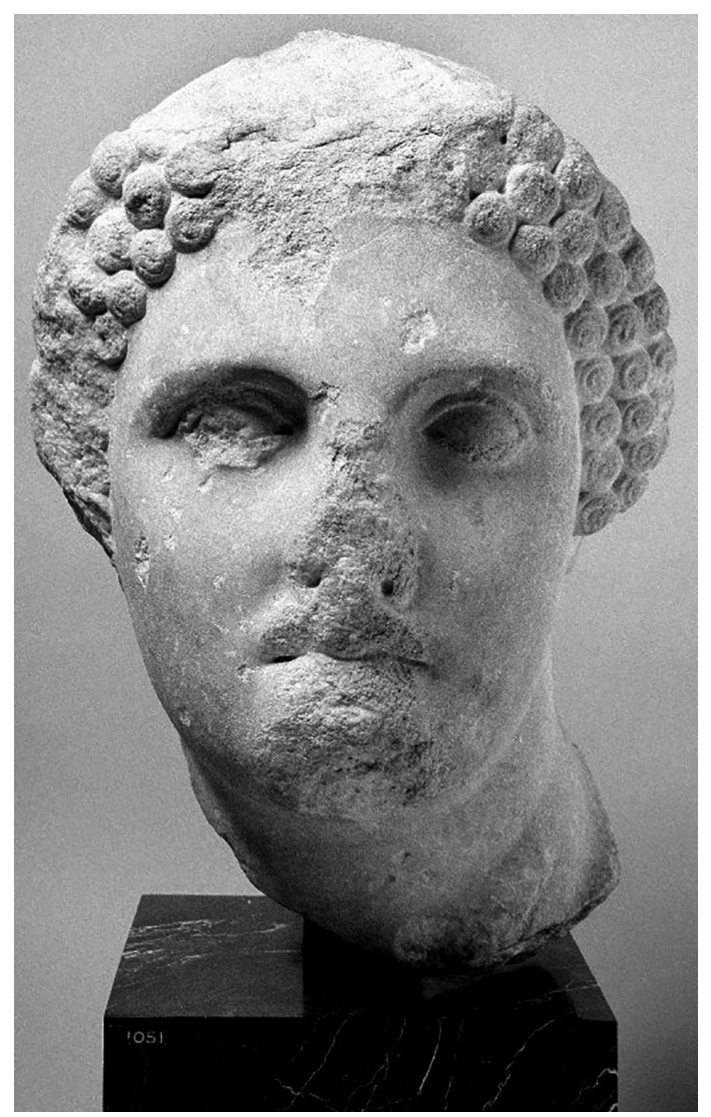

Fig. 6. Marble head, London, The British Museum, Greek and Roman Department, no. 1051

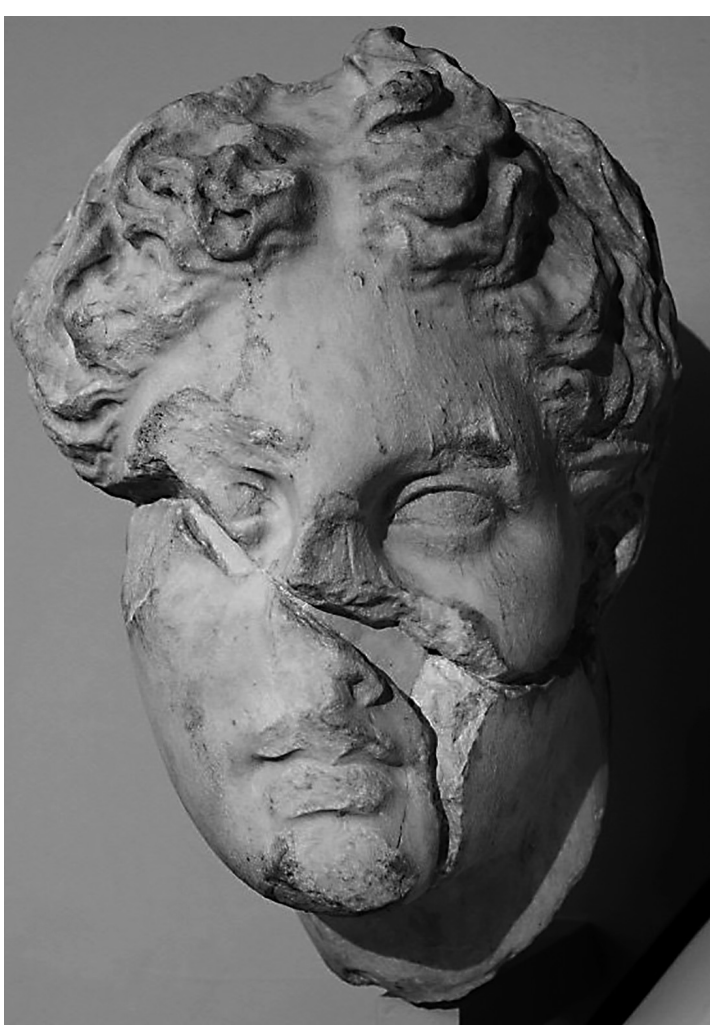

Fig. 7. Marble head, London, The British Museum, Greek and Roman Department, no. 1058 (photo courtesy of late Prof. G. B. Waywell).

Moreover the colossal head of a Carian noble lady at London, BM 1051 (Fig. 6) ${ }^{29}$, responds well to the general concept of face and to its anatomic grammar which has been recognized to be typical of the atelier of this sculptor.

Especially the head of Apollo at London, BM 1058 (Fig. 7), perhaps to be included in the series of heroic size statues ${ }^{30}$, is so

${ }^{29}$ See Waywell 1978: pl. 16, no. 30 and Lucchese 2009: pl. 2 a. Jeppesen 2002: 5. 194-199 regards this head pertinent to an acroterial group: however in that case the surface should be much more weathered. Concept of face and of its anatomic grammar in Leochares: see Todisco 1993: figs. 219 (Vatican type of Ganymedes kidnapped by the eagle); 220 (Basle type of Apollo diadematus); 213 (Acropolis type of Alexander) and 226-227 (Belvedere type of Apollo). About the Belvedere type of Apollo as the copyist tradition derived from Leochares' Apollo Patroos, see Maderna 2004: 341-344.

${ }^{30}$ Waywell 1978: pl. 22, no. 48 and Lucchese 2009: pl. 4 a. 
close to the head of the Belvedere type of Apollo to eloquently confirm that the master of the latter did work for statues of the Mausoleum.

This head should be given to Leochares and not to his assistants because of its very high quality and since it reveals clearly the art of this master.

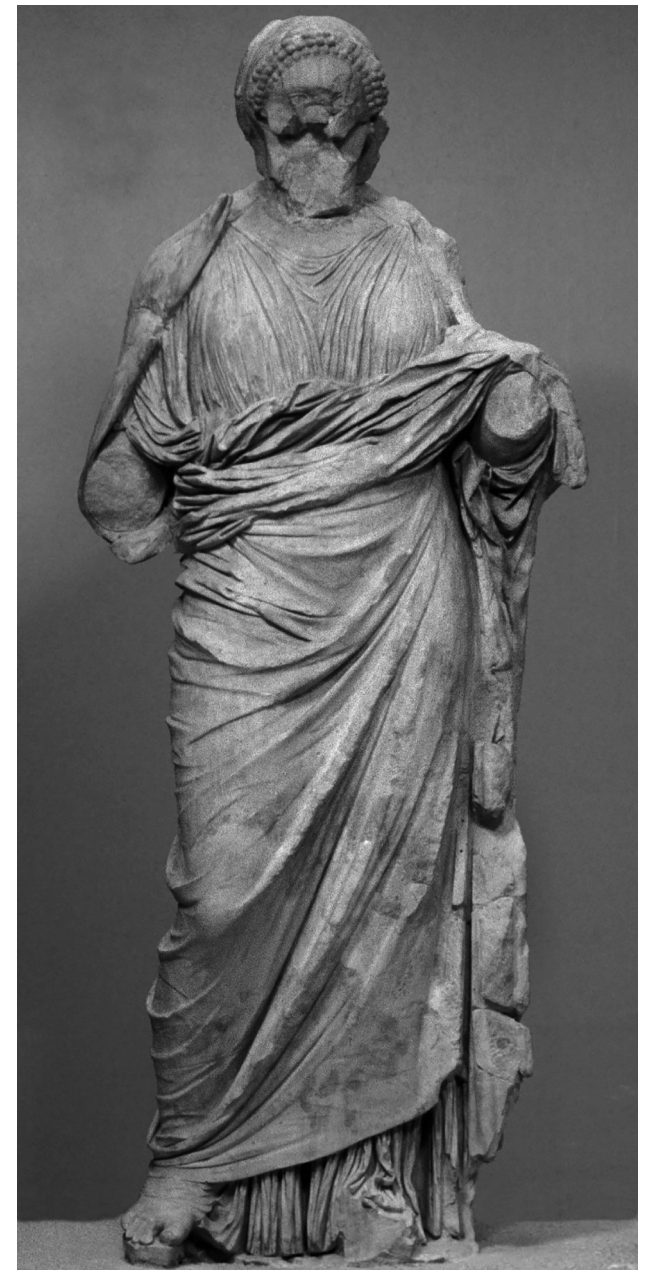

Fig. 8. So-called 'Artemisia', marble, London, The British Museum, Greek and Roman Department, no. 1001

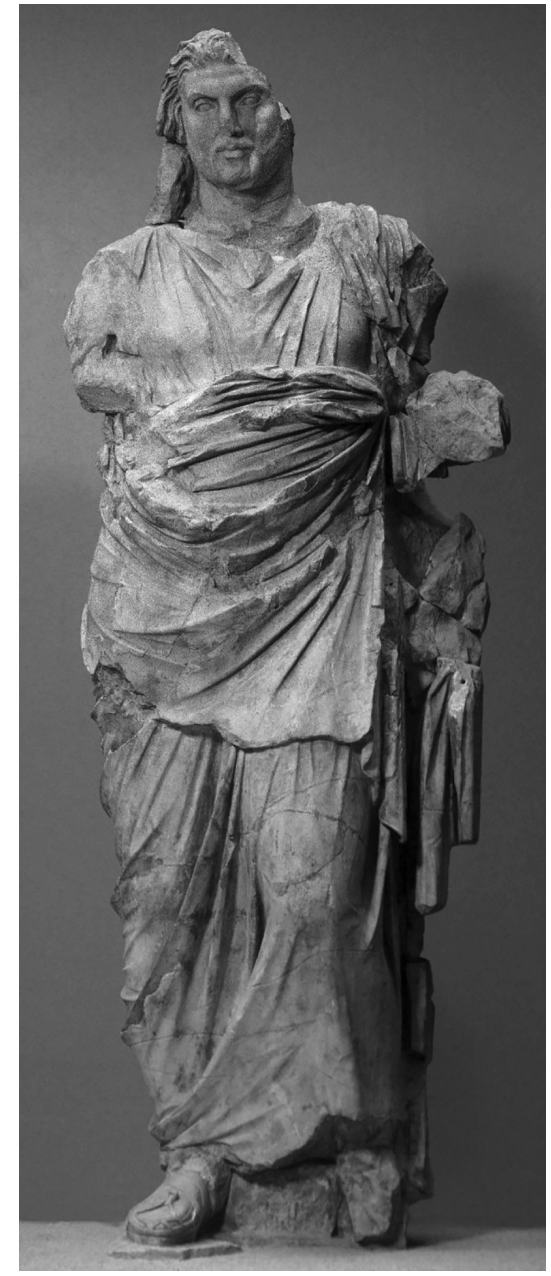

Fig. 9. So-called 'Mausolus', marble, London, The British Museum, Greek and Roman Department, no. 1000

\section{Sculptures to be attributed to Bryaxis.}

Bryaxis is recognized in the colossal statues of Carian dignitaries at London, BM 1001 (Fig. 8) and 1000 (Fig. 9) ${ }^{31}$, because they reveal a heavy, static and frontal concept of figures which would suggest the name of the only sculptor who worked for

\footnotetext{
${ }^{31}$ I refer to the so-called Artemisia and Mausolus: see Waywell 1978: pls.
} 13-15 and Lucchese 2009: pl. 1, a and b. 
the Mausoleum and had Carian roots. The very high quality of these two statues - and especially the face of the male aristocrat which is itself a masterpiece of psychological rendering - would suggest their attribution to the master and not to his assistants.

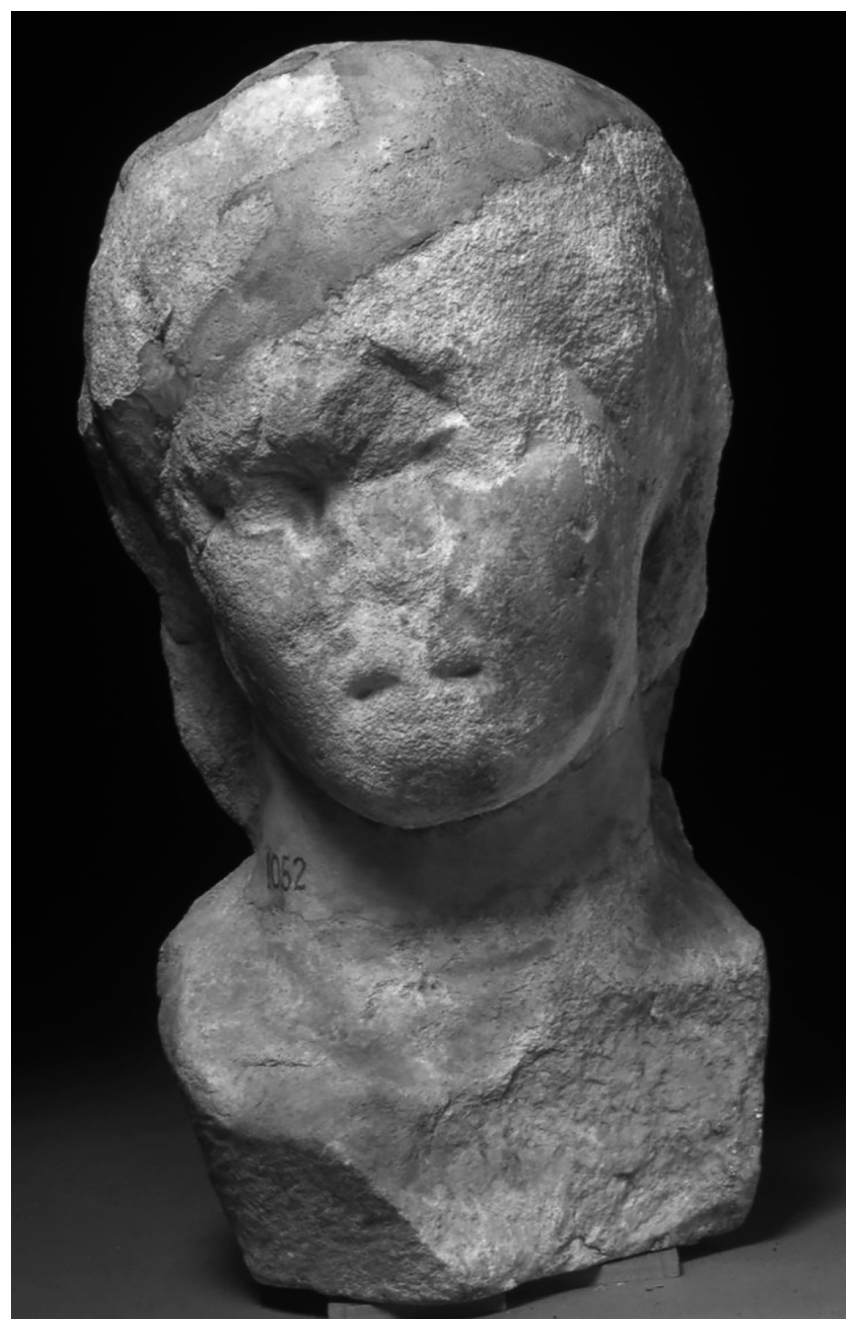

Fig. 10. Marble head, London, The Greek and Roman Department, no. 1052 (photo courtesy of late Prof. G. B. Waywell).

\section{Sculptures to be attributed to Praxiteles.}

The problem of recognizing Praxiteles' art in the Mausoleum is suggested by the colossal female head at London, BM 1052 (Fig. 10) ${ }^{32}$. This head was inserted into a draped statue: the upper edge of a himation was pulled on the head from the left side. The face is oval, the forehead's upper border was curved, eyes and eyesockets were narrow and elongated, the surface is fleshed out with the typically Praxitelean light-and-shade rendering, the curving of

${ }^{32}$ Waywell 1978: 107-108, no. 31 and pl. 17. 
the neck is similar to that of the Cnidia. The head must have conveyed the appeal and freshness of a young lady and is graciously tilted and inclined to her right. I recognize in this work the concept of young female beauty of Praxiteles.

Comparison with the heads of Hecatomnid ladies at London, The British Museum, nos. 1001 and 1051 clarifies that probably this head portrayed a young lady of the Carian court: probably her statue was one of the colossal images disposed in the intercolumns of the peristasis. Unfortunately the re-use of this head in the chimney of the Imam's house near the Mausoleum does not allow the determination of the side of the Mausoleum in which the colossal statue was set up.

Another fragment which should be given to Praxiteles is the left foot on sandal of a female figure pertaining to the heroic standing statues: the foot is at London, BM 1972.4-2.172(261) ${ }^{33}$. The shape of the sandal which bears an indentation between the big toe and the second toe, and its relation with the toes, finds comparison in the feet with sandals of the Gabii type of Artemis and of the Hermes of Olympia. I specify here that the old opinion that indentations in footwear appear only from around $300 \mathrm{BC}$ is now discredited because $\mathrm{H}$. Froning demonstrated that there are several examples of indented footwear which are still late classical ${ }^{34}$.

Praxiteles may have adopted this type of sandal for his statues of young females because it was curvaceous and graceful, thus in keeping with the appeal and female seduction spreading from these dreamy figures. Again the re-use of this fragment in a Turkish house does not guarantee its coming from a specific side of the building.

These two fragments lend support to the conclusion that Praxiteles was haired in order to carve statues of young female subjects for the two series of colossal and heroic statues.

Clearly the Cnidian Aphrodite must have established in Caria the renown of Praxiteles especially as a great interpreter of girlish beauty.

\section{The Lions.}

Finally several lions which probably stood at the base of the pyramidal roof of the building may be relevant to the issue discussed

\footnotetext{
${ }_{34}^{33}$ Waywell 1978: no. 228 and fig. 33.

${ }^{34}$ About this type of sandals, Corso 2000: $125-161$ and Froning 2007: 95101.
} 
in this article ${ }^{35}$. The lions were carved for a profile view. They were standing but about to walk. Their left legs are more advanced when compared to their right legs. Their manes are made of short and sinuous locks. Their tails are also long and sinuous. The iconography of the lions must have been provided by the designers of the building and the sculptors had to abide by that.

However the detailed rendering of patterns of these lions differs greatly in this series and thus it is possible to distinct the animals in different groups according to their specific styles (Waywell 1978: 32-34).

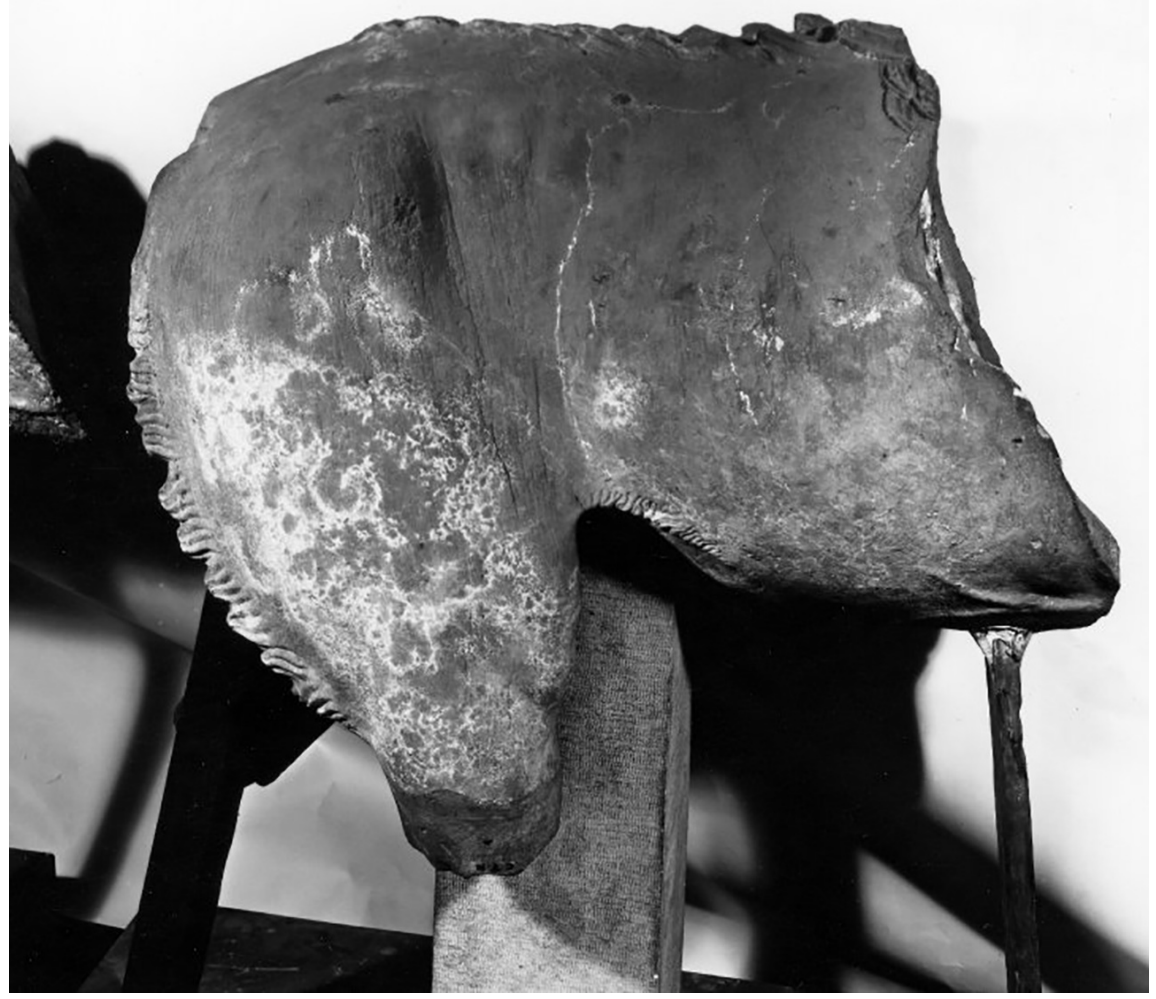

Fig. 11. Marble lion, London, The Greek and Roman Department, no. 1085 (photo courtesy of late Prof. G. B. Waywell).

The rear sides of these lions were marked with Greek letters. A lion from the NE corner of the building - London, BM 1085 (Fig. 11) - bears the letter A on its back (Waywell 1978: 187-188, no. 416). Since the master of the eastern side was Scopas, it is

\footnotetext{
${ }^{35}$ Waywell 1978: 27-34 and 180-209, pls. 37-42. Waywell supposed that the lions were disposed on the lowest step of the pyramidal roof in series from the corners looking toward the middle of each side of the building. Jeppesen 2002: 5. 118-124 believes that the lions were disposed in couples, looking to a pillar placed between them, on several steps of the pyramidal roof. The available evidence does not allow the resolution of the problem of the exact disposition of the lions.
} 
possible that $\mathrm{A}$ is the initial of the name of the father of Scopas, Aristandros of Paros ${ }^{36}$. He may have been the legal owner of the workshop, which is why his initial letter would mark lions on the eastern side. The lions must have been made by assistants because they were second-rate sculptures, destined to be seen from far away.

This lion and the lion London, BM 1082 (Fig. 12) ${ }^{37}$, reveal an emphasis on the wildness of the lion with a triple row of locks, a protruding tongue and open, spirited eyes. These features are in keeping with the fire and expression of extreme attitudes which are typical of the style of Scopas.

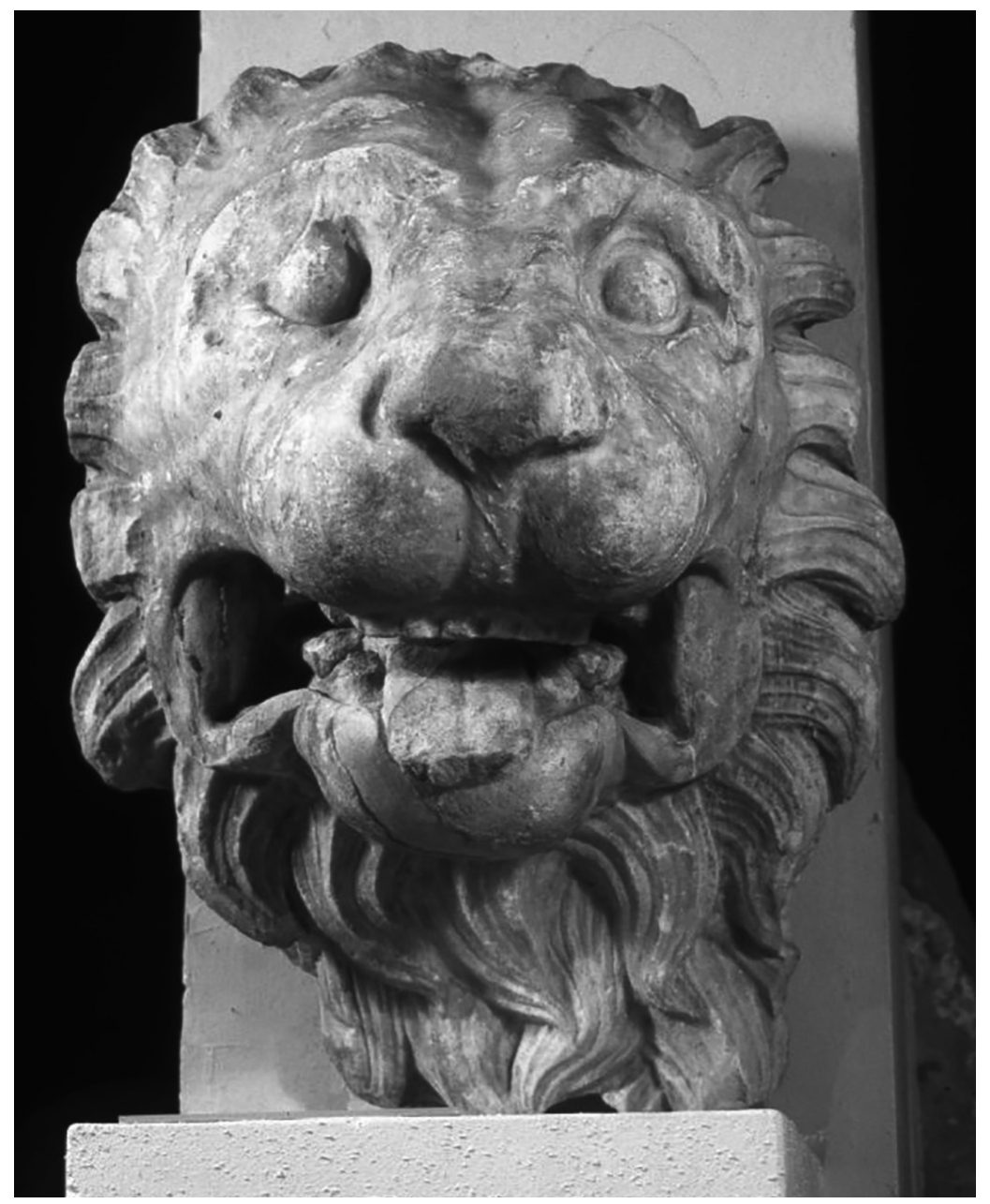

Fig. 12. Marble lion, London, The Greek and Roman Department, no. 1082 (photo courtesy of late Prof. G. B. Waywell).

The presence of letter marks suggests that the lions were carved in the workshops of the masters charged of them and shipped to

\footnotetext{
${ }^{36}$ About Aristandros, see Pausanias 3. 18. 8: Kourinou-Pikoula 1994: 803804 and Mueller and Broeker 2001: 80.

${ }^{37}$ Waywell 1978: 186, no. 414 and pl. 40.
} 
Halicarnassus where the letters clarified where they should be set up on the Mausoleum.

Other lions bear the letter $\Pi$ on their backs: these lions are at London, BM 1075, 1081, 1084 and 1086. Other lions, whose backs do not survive and thus no longer bear letter marks, are stylistically related to this series: these lions are at London, BM 1076; 1083; MRG 116 Reg. 1857 12-20. 244. 283 (Waywell 1978: 180-186, nos. 401-403; 407; and 410-412). These lions have been carved by three sculptors (nos. one, two and three in Waywell's catalogue) and nevertheless are closely linked: probably these three craftsmen working in the same workshop (Waywell 1978: 32-33). This set of animals was set up on the northern side of the monument. The $\Pi$ letter could be interpreted as referring to either Pytheus or Praxiteles, both artists having worked for the Mausoleum according to the ancient tradition.

However Pytheus should be excluded because he is not listed among the sculptors charged with statues displayed on the four sides.

Praxiteles is a possible option. In the rendering of the surface of the bodies of these lions, the smoothness prevails upon anatomic details, their poses are lithe and curved patterns are preferred: the latter feature is clear especially in the rounded corners of the mouth. The eye-sockets are carved with sense of the transitions. These patterns are stylistic features of the workshop of Praxiteles. Thus it is possible that these three sculptors were workshop's craftsmen, charged with the lions because these animals on the roof, set up to be seen from a far distance, were regarded second-rate. These lions, prepared in Praxiteles' workshop by attendants, may have been shipped from Athens to Halicarnassus, where the $\Pi$ letter must have shown their pertinence to the northern side.

Then there are three lions which bear the letter $\Lambda$ : they are at London, BM 1078; MRG 114 Reg. 1857. 12-20. 246 and MRG 113 Reg. 1857. 12-20. 254. The lion at London BM $1077^{38}$ is stylistically close to these examples but its back does not survive and also its letter mark.

Since the eastern lions bore the A mark and the northern ones the $\Pi$ mark, the lions with the $\Lambda$ mark must have been pertinent to either the western or the southern side. Their style is revealed by the spiky treatment of their manes as well as by their not deep-set eyes: a feature which must have implied a great emphasis on the

${ }^{38}$ Waywell 1978: 182-188, nos. 404, 408, 415 and 417. 
expression of eyes (Waywell 1978: 33). Since these patterns are in keeping with the style of Leochares, it is tempting to think that $\Lambda$ is the initial of Leochares and that the lions pertained to the western side.

I wish to suggest that the lions at London, BM 1079 and $1080^{39}$ with round eyes, upturned heads, pathetic gazes and tufty manes and fur are close to the art of Scopas, thus they should be attributed to a sculptor working in the atelier of the Parian master and be given to the eastern side.

The interpretation of the letter marks of the lions given here is the only one which makes sense. An alternative explanation could be that the letters were the initials of the names of the craftsmen of these lions: the circumstance that three sculptors (nos. one, two and three in Waywell's list) carved lions bearing the same $\Pi$ letter makes this hypothesis unlikely. Another possibility could be that these letters referred to the sides where these lions had to be set up. This suggestion is also unsatisfactory because there are not cardinal points whose names begin with $\Lambda$ and $\Pi$ in ancient Greek. The suggestion that they are alphabetic sequences or numerals does not make sense: in these cases there should not be several lions with the same letters.

The lions protected the monument from above and expressed the power and strength of the Hecatomnids (Jeppesen 2002: 5, 118124).

Since the $\Pi$ lions stood on the northern side and fragments of two free-standing statues attributed to Praxiteles' workshop were found re-used in post-ancient buildings on north of the Mausoleum, perhaps the sculptures commissioned from him stood on this side.

Thus Bryaxis' activity on the northern side, asserted by Pliny, may refer only to reliefs and it is possible that in free-standing sculpture he picked up the southern side. Given his Carian roots, Bryaxis may have been able to secure the most prestigious southern side in the most important realm of the free-standing sculpture.

This hypothesis would explain the sequence of names of the four sculptors in Vitruvius: coming from the sea - thus from west to east - he mentioned first of all Leochares, the master of the western side, then Bryaxis, responsible for statues in the southern side, then Scopas, the master of the eastern side, and finally Praxiteles, who worked for the northern side.

${ }^{39}$ Waywell 1978: 33, 182-183, no. 405, and 186, no. 413. 


\section{Conclusive remarks}

The attributions to specific masters who worked on the Mausoleum suggested here are in most cases original contributions. Only the statues of the so-called Artemisia and Mausolus had been previously attributed to Bryaxis and the head BM 1058 had been given to Leochares, especially by Todisco. The letters $\Lambda$ and $\Pi$ on lions had been already related to Leochares and Praxiteles but only generically, without comparison of these lions with other works of these masters. Waywell accepted that the sculptors mentioned by Pliny worked for the Mausoleum but did not try to attribute specific free-standing sculptures to them, while Cook is rather skeptical about the work of these masters on reliefs from the Mausoleum.

The interest of the most famous Greek marble sculptors of the time to work for the satraps of Asia Minor is probably due to lack of sizable monumental programs in the same period in the world of the Greek poleis. During these years most Greek states were engaged in continuous wars and for this reason had only a limited economic capability to promote new monuments (Buckler 2003: 184-524).

On the contrary the satraps of western Asia Minor had the vision, the managerial attitude, the enterprising skills and the economic capability to build new cities, such as Halicarnassus and Priene, and to promote monuments destined to enjoy a great fame for a long period, such as the Mausoleum.

\section{Bibliography}

Broeker, G. 2001: Aristandros (I), in R. Vollkommer (ed.), Kuenstlerlexikon der Antike 1, Muenchen, 80.

Buckler, J. 2003: Aegean Greece in the Fourth Century BC, London.

Calcani, G. 2009: Skopas di Paros, Roma.

Carstens, A. M. 2009: Karia and the Hekatomnids, Oxford.

Cook, B. F. 2005: Relief Sculpture of the Mausoleum at Halicarnassus, Oxford.

Corso, A. 2000: Small Nuggets about late-classical Sculpture, NumAntCl $29,125-161$.

Corso, A. 2004-2014: The Art of Praxiteles I-V, Rome.

Corso, A. 2007a: The Art of Praxiteles 2, Rome.

Corso, A. 2007b: The Cult and Political Background of the Knidian Aphrodite, Proceedings of the Danish Institute at Athens 5, 173197.

Despinis, G. 2004: Akrolithstatuen Griechischer und Roemischer Zeit, Akademie der Wissenschaften zu Goettingen 8, 243-301.

Flensted-Jensen, P. 2004: Halikarnassos, in M. H. Hansen and T. H. Nielsen (eds.), An Inventory of Archaic and classical Poleis, Oxford, 1115-1116. 
Froning, H. 2007: Die Sandale des Hermes des Praxiteles in Olympia, in E. Christof (ed.), Potnia Theron, Wien, 95-101.

Geraci, G. 2004: Mensura, pondus e probatio, in R. Soraci (ed.), Politica, retorica e simbolismo, Catania, 115-181.

Gros, P. 2006: Vitruve, Roma.

Gruben, G. 1999: Wandernde Saeulen auf Naxos, N. C. Stampolidis (ed.), Phos Kykladikon, Athina, 296-317.

Hallof, K. and Kansteiner, S. 2014: Satyros, in S. Kansteiner (ed.), Der neue Overbeck 3, Berlin, 471-473.

Hallof, K, Kansteiner, S. and Lehmann, L 2014 a: Leochares, in S. Kansteiner (ed.), Der neue Overbeck 3, Berlin, 210-239.

Hallof, K, Kansteiner, S. and Lehmann, L 2014 b: Bryaxis, in S. Kansteiner (ed.), Der neue Overbeck 3, Berlin, 478-506.

Hoepfner, W. 2002: Das Mausoleum von Halikarnassos, in W. D. Heilmeyer (ed.), Die Griechische Klassik, Berlin, 417-423.

Hoepfner, W. 2004: Pytheos, in R. Vollkommer (ed.), Kuenstlerlexikon der Antike 2, Muenchen 334-338.

Hornblower, S. 1982: Mausolus, Oxford.

Jenkins, I. 2010: The Mausolea of Halicarnassus, in F. MacFarlane and C. Morgan (eds.), Exploring ancient sculpture, London, 121-135.

Jeppesen, K. (ed.) 1981-2002: The Mausoleion at Halikarnassos, vols. 17, Aarhus.

Jeppesen, K. 1981-1983: Did Vitruvius ever visit Halikarnassos?, Anadolu $21,85-98$.

Kansteiner, S., Lehmann, L. and Prignitz, S. 2014: Timotheos, in S. Kansteiner (ed.), Der neue Overbeck 3, Berlin, 279-285.

Kansteiner, S. and Seidensticker, B. 2014: Pytheos, in S. Kansteiner (ed.), Der neue Overbeck 3, Berlin, 506-509.

Katsonopoulou, D. and Stewart, A. 2013: Skopas of Paros, Athens.

Kourinou-Pikoula, E. 1994: Sparta, LIMC 7, 803-804.

Loehr, C. 2000: Griechische Familienweihungen, Rahden.

Lucchese, C. 2009: Il Mausoleo di Alicarnasso e i suoi maestri, Roma.

Maderna, C. 2004: Die letzten Jahrezehnte der spaetklassischen Plastik, in P. Bol (ed.), Die Geschichte der antiken Bildhauerkunst 2, Mainz, 303-382.

Oestby, E. 2014: Tegea, Athens.

Ruzicka, S. 1992: Politics of a Persian Dynasty. The Hecatomnids in the Fourth Century B. C., Oklahoma.

Schultz, P. 2007: Leochares' Argead Portraits in the Philippeion, P. Schultz and R. von den Hoff (eds.), Early Hellenistic Portraiture, Cambridge, 205-233.

Schweitzer, B. 1967: Alla ricerca di Fidia, Milan.

Soeldner, M., Hallof, K., Krumeich, R. and Seidensticker, B. 2014: Praxiteles, in S. Kansteiner (ed.), Der neue Overbeck 3, Berlin, 49209.

Stampolidis, N. 2007: Symplegma Ermi kai mikrou Dionysou, in N. Kaltsas and G. Despinis (eds.), Praxitelis, Athina, 90-97.

Stewart, A. 2004: Timotheos (ii), in R. Vollkommer (ed.), Kuenstlerlexikon der Antike 2, Muenchen, 475-479. 
Svensen-Evers, H. 1996: Due Griechische Architekten archaischer und klassischer Zeit, Frankfurt.

Tandy, D. 2013: Skopas of Paros, in D. Katsonopoulou and A. Stewart (eds.), Skopas of Paros, Athens, 65-75.

Vollkommer, R. 2001: Bryaxis, in R. Vollkommer (ed.), Kuenstlerlexikon der Antike 1, Muenchen, 122-125.

Vorster, C., Lehmann, L. and Zerhoch, S. 2014: Skopas, in S. Kansteiner (ed.), Der neue Overbeck 3, Berlin, 417-470.

Waywell, G. B. 1978: The free-standing Sculpture of the Mausoleum of Halicarnassus in the British Museum, London.

Waywell, G. B. 2004: Satyros (I), in R. Vollkommer (ed.), Kuenstlerlexikon der Antike 2, Muenchen, 366-367.

Yalouris, N. 1992: Die Skulpturen des Asklepiostempels in Epidauros, Muenchen. 